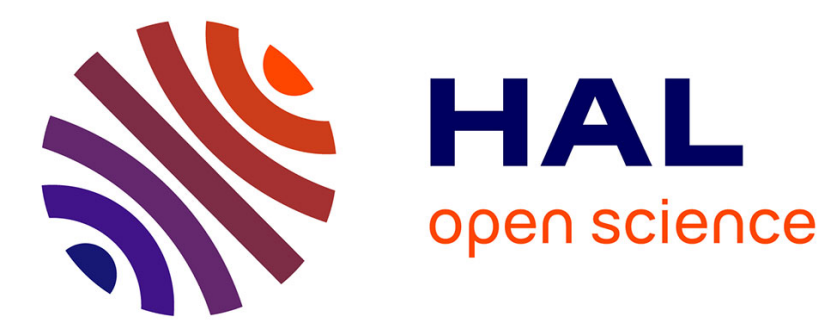

\title{
Impact of serum tumor marker determination on the management of women with borderline ovarian tumors: Multivariate analysis of a french multicentre study
} C. Poncelet, R. Fauvet, C. Yazbeck, C. Coutant, E. Darai

\section{- To cite this version:}

C. Poncelet, R. Fauvet, C. Yazbeck, C. Coutant, E. Darai. Impact of serum tumor marker determination on the management of women with borderline ovarian tumors: Multivariate analysis of a french multicentre study. EJSO - European Journal of Surgical Oncology, 2010, 36 (11), pp.1066. 10.1016/j.ejso.2010.07.004 . hal-00630333

\section{HAL Id: hal-00630333 \\ https://hal.science/hal-00630333}

Submitted on 9 Oct 2011

HAL is a multi-disciplinary open access archive for the deposit and dissemination of scientific research documents, whether they are published or not. The documents may come from teaching and research institutions in France or abroad, or from public or private research centers.
L'archive ouverte pluridisciplinaire HAL, est destinée au dépôt et à la diffusion de documents scientifiques de niveau recherche, publiés ou non, émanant des établissements d'enseignement et de recherche français ou étrangers, des laboratoires publics ou privés. 


\section{Accepted Manuscript}

Title: Impact of serum tumor marker determination on the management of women with borderline ovarian tumors: Multivariate analysis of a french multicentre study

Authors: C. Poncelet, R. Fauvet, C. Yazbeck, C. Coutant, E. Darai

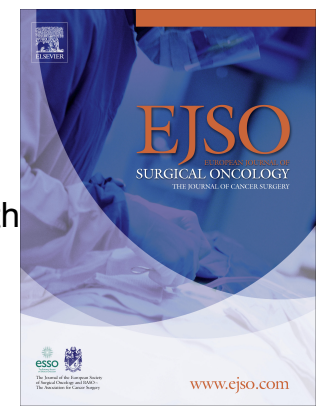

PII:

S0748-7983(10)00308-2

DOI:

10.1016/j.ejso.2010.07.004

Reference: YEJSO 3022

To appear in: European Journal of Surgical Oncology

Received Date: 19 April 2009

Revised Date: 12 July 2010

Accepted Date: 15 July 2010

Please cite this article as: Poncelet C, Fauvet R, Yazbeck C, Coutant C, Darai E. Impact of serum tumor marker determination on the management of women with borderline ovarian tumors: Multivariate analysis of a french multicentre study, European Journal of Surgical Oncology (2010), doi: 10.1016/ j.ejso.2010.07.004

This is a PDF file of an unedited manuscript that has been accepted for publication. As a service to our customers we are providing this early version of the manuscript. The manuscript will undergo copyediting, typesetting, and review of the resulting proof before it is published in its final form. Please note that during the production process errors may be discovered which could affect the content, and all legal disclaimers that apply to the journal pertain. 
IMPACT OF SERUM TUMOR MARKER DETERMINATION ON THE

MANAGEMENT OF WOMEN WITH BORDERLINE OVARIAN TUMORS:

MULTIVARIATE ANALYSIS OF A FRENCH MULTICENTRE STUDY.

C PONCELET ${ }^{1-2}, \mathrm{R} \mathrm{FAUVET}^{1}, \mathrm{C} \mathrm{YAZBECK}^{3}, \mathrm{C} \mathrm{COUTANT}^{1}$, and E DARAI ${ }^{1}$ *

1. Service de Gynécologie-Obstétrique, Hôpital Tenon, AP-HP, CancerEst, Université Pierre et Marie Curie Paris VI, France.

2. UFR SMBH Léonard De Vinci, Université Paris XIII, 93017 Bobigny Cedex, France.

3. Unité INSERM U 472. Faculté de Médecine Paris Sud. 63 rue Gabriel Péri. 94276 Le Kremlin Bicêtre Cedex.

*Correspondence:

Professor Emile Daraï, MD, PhD

Service de Gynécologie-Obstétrique

Hôpital Tenon, 4 rue de la Chine

75020 Paris, France

Tel: 33156017318

Fax: 33156017317

E-mail: emile.darai@tnn.ap-hop-paris.fr

Short title: Tumor markers and borderline ovarian tumors 


\section{Condensation:}

Preoperative evaluation of serum tumor markers impacts on the management of borderline ovarian tumors. 
Impact of serum tumor marker determination on the management of women with

borderline ovarian tumors: multivariate analysis of a French multicentre study.

C PONCELET, R FAUVET, C YAZBECK, C COUTANT, and E DARAI.

\section{ABSTRACT:}

Objective: To evaluate the contribution of preoperative serum tumor markers to manage borderline ovarian tumors (BOT).

Study Design: Retrospective multicentre study including 317 BOT. Serum tumor marker levels of CA125, CA19-9, CEA, and CA15-3 were determined by radio-immunoassay.

Results: Among 181 women with serous BOT and 136 women with mucinous BOT, respectively 55 of $114(48.2 \%)$ and 38 of $91(41.8 \%)$ had at least one abnormal value. Women with preoperative tumor marker assays were more likely to have radical treatment $(p=0.0001)$, full staging $(\mathrm{p}=0.004)$, and intraoperative histology $(\mathrm{p}<0.0001)$. Women with at least one abnormal tumor marker were more likely to undergo laparotomy $(\mathrm{p}=0.007$ ), to have intraoperative histology $(\mathrm{p}=0.04)$ and complete staging $(\mathrm{p}=0.0008)$. In multivariate analysis, first-line laparoscopy was associated with abnormal tumor marker levels $(\mathrm{OR}=9.63$; 95\% CI=1.40-66.39; $\mathrm{p}=0.02$ ), while laparotomy was associated with large tumors, bilateral tumors, and ascitis visible on sonography.

Conclusion: Serum tumor marker assays modified both preoperative assessment and surgical management of BOT.

Key words: borderline ovarian tumors, CA125, CEA, CA15-3, CA19-9, tumor markers. 


\section{INTRODUCTION}

Accepted as a distinct histological entity by the International Federation of Gynecology and Obstetrics (1) and the World Health Organization (WHO) (2) in the early 1970 s, borderline ovarian tumors account for $10 \%$ to $20 \%$ of ovarian epithelial tumours (3). Guidelines for surgical treatment are similar to those for ovarian cancer (4-5). However, one third of borderline ovarian tumors are diagnosed in women younger than 40 years, and more than $80 \%$ of cases are detected early in the disease course, raising issues of fertility-sparing surgery, laparoscopic management, and restaging operations (6-15).

Diagnosis of adnexal masses is mainly based on imaging techniques and preoperative serum tumor marker assays (16-21). Serum tumor markers have been evaluated in only small series of women with BOT, and their contribution to treatment and follow-up is unclear (2224).

Elevated serum tumor markers such as CA125, CEA and CA19-9 have been reported in only $25 \%$ to $60 \%$ of women with BOT $(18,23-25)$.

The aims of this retrospective study were to evaluate the contribution of the serum tumor markers CA125, CA19-9, CEA and CA15.3 to the initial management of women with BOT, and to determine their value for detecting recurrences. 


\section{MATERIAL AND METHODS}

\section{MATERIAL}

From January to December 2001 we conducted a retrospective multicenter study of 360 women treated for BOT between 1990 and 2000 in 13 specialized gynecology units and one cancer center. Women with endometrioid (four cases), Brenner (2 cases) and mixed BOT (32 cases) were excluded from the study. The study population thus comprised 322 patients with serous or mucinous BOT. Data were obtained from hospital records, physicians, and direct contact with the patients. All the charts were thoroughly reviewed on site by one of the authors (RF). Ethical review board approval was obtained for the study.

The histological type was established by reviewing hematoxylin/eosin-stained slides, as recommended by FIGO (4). The following histological criteria were used to identify borderline tumors: (a) stratification of the epithelial lining of the papillae, with microscopic papillary projections or tufts arising from the epithelial lining of the papillae, (b) nuclear atypia, (c) mitotic activity, (d) intracystic clusters of free-floating cells, and (e) absence of stromal invasion. Microinvasion and micropapillary features were also recorded.

\section{METHODS}

Surgical treatment was considered conservative when at least one ovary and the uterus were spared. Conservative treatment consisted of unilateral cystectomy (UC) or unilateral salpingo-oophorectomy (USO), as well as bilateral cystectomy (BC) and USO + contralateral UC (USO+UC). Initial surgery was considered to be a complete staging operation when all peritoneal surfaces were carefully inspected and peritoneal washing, multiple random or oriented biopsies, and infra-colonic omentectomy were performed. Appendectomy was also a criterion for complete staging of mucinous borderline tumors. Initial surgery was considered an incomplete staging operation in all other cases, independently of the radical or 
conservative nature of treatment. The disease was staged as recommended by the International Federation of Gynecology and Obstetrics (4).

\section{SERUM TUMOR MARKERS}

Serum levels of CA-125, CA-19.9, CEA and CA-15.3 were measured with radioimmunoassays. Values were considered elevated when CA-125 > 35 IU, CA-19.9 > 40 IU, CEA > $5 \mathrm{IU}$ and CA-15.3 > $30 \mathrm{IU} / \mathrm{ml}$. Serum tumor marker levels in a given patient were considered abnormal if at least one of the markers was elevated.

Five of the 322 women had preoperative serum tumor marker assays that were not mentioned in the charts, and these women were excluded from the statistical analysis.

\section{STATISTICAL ANALYSIS}

Univariate analysis was used to compare epidemiological and surgical data between patients with and without preoperative serum tumor marker assays in the entire study population. Then, in the population of women who had preoperative serum tumor marker assays, univariate analysis was used to compare epidemiological and surgical data in patients with normal and abnormal marker status. The chi-square test and Student's t test were used to compare non continuous and continuous variables in univariate analysis.

Multivariate analysis was used to determine the diagnostic and prognostic relevance of preoperative serum tumor markers, and their contribution to detecting recurrences. The primary endpoint in the multivariate model was recurrence. Preoperative pelvic CT, first-line laparoscopic management, and the use of intra-operative histology were secondary endpoints. Associations between clinical, sonographic and serum tumor marker parameters (CA-125, CA-19.9, CEA, CA-15.3) and the above endpoints were identified by multivariable logistic regression analysis. When serum markers were assayed, an additional analysis included the marker level as a binary variable (normal or abnormal). 
Correlations between parameters were studied to prevent the selection of strongly correlated parameters in the logistic model. As age and menopause were strongly correlated (correlation coefficient $0.77, p<10^{-4}$ ), we decided to consider age alone and to exclude menopause from further multivariate analyses. Odds ratios (OR) and 95\% confidence intervals (CI), as well as $p$-values, were calculated for both dichotomous and continuous variables.

Backwards elimination was used to select prognostic factors for the different endpoints. It started with a model that contained all explanatory variables identified by univariate analysis. This algorithm eliminated non significant variables and refitted the model repeatedly. This analysis used a significance level of 0.2 to retain variables in the model. To minimize erroneous exclusion of serum markers which could be of prognostic relevance, these markers were forced into the models.

To measure the association between predicted probabilities and observed responses, the reliability of the models was studied with Somer's test statistic. The convergence criterion was satisfied in all models. All significance tests were two-tailed and $p$ values $<0.05$ were considered significant. SAS software version 8.2 was used for all statistical analyses. 


\section{RESULTS}

Study population, and distribution of FIGO stage, type of surgery and biomarkers serum levels according to histological subtype

Among the 317 women included in this analysis, respectively 181 and 136 women had serous and mucinous BOT. Among the women with serous and mucinous tumors, respectively 114 and 91 women had preoperative serum tumor marker assays, of whom respectively 55 and 38 had at least one abnormal result. Details are given in Table 1. In the group of serous tumors, 82 had laparoscopy, with laparoconversion in 21 cases, and 99 laparotmy and the distribution according to FIGO stage was Ia, Ib, Ic, II, III, and IV in 114, $28,18,8,12$, and 1 patients, respectively. In the group of mucinous tumors, 49 had laparoscopy, with laparoconversion in 9 cases, and 87 laparotomy and the distribution according to FIGO stage was Ia, Ib, Ic, II, III, and IV in 122, 3, 3, 1, 6, and 1 patients, respectively. In the group of serous tumors, the distribution of abnormal biomarkers according to FIGO stage Ia, Ib, Ic, II, III, and IV was $25,9,5,4$, 4, and 1 patients, respectively. In the group of mucinous tumors, the distribution of abnormal biomarkers according to FIGO stage Ia, Ib, Ic, II, III, and IV was 30, 1, 2, 0, 3, and 1 patients, respectively.

Epidemiological and surgical characteristics of women with and without preoperative serum tumor marker assays (Table 2).

Two hundred and five of the 317 women had preoperative serum tumor marker assays. Women with preoperative serum tumor marker assays were older $(\mathrm{p}=0.001)$, had higher parity $(\mathrm{p}=0.03)$ and were more likely to be menopausal $(\mathrm{p}=0.02)$. In addition, these women were more likely to have CT scan $(\mathrm{p}<0.0001)$ and/or MRI $(\mathrm{p}=0.03)$ before surgery.

Whatever the results of preoperative serum tumor marker assays, women who had these tests were more likely to have radical treatment $(\mathrm{p}=0.0001)$ and full staging $(\mathrm{p}=0.004)$, including peritoneal washing $(\mathrm{p}<0.0001)$ and random peritoneal biopsies $(\mathrm{p}<0.0001)$. 
Intraoperative histology was more frequent among women who had preoperative serum tumour marker assays $(\mathrm{p}<0.0001)$. Recurrences were more frequent in women without preoperative tumour marker assays $(\mathrm{p}=0.03)$.

The women who did and did not have preoperative serum tumor marker assays did not differ with respect to their familial history of cancer, number of pregnacy, presenting symptoms, tumor size on sonography, or the use of first-line laparoscopy, exclusively laparoscopic surgery, optimal cytoreductive surgery, or restaging operation. Mean follow-up among women with and without preoperative tumor marker assays was $34.4 \pm 2.6$ months and $40 \pm 5.1$ months, respectively (not significant). Mean disease-free survival was similar in the two groups.

\section{Impact of preoperative serum tumor marker assays on BOT management}

Ninety-three of the 205 women with preoperative serum tumor marker assays had at least one abnormal result, and were thus considered to have abnormal serum tumor marker status (Table 3). These women were more likely to have large tumors $(\mathrm{p}=0.001)$, bilateral tumors $(\mathrm{p}=0.01)$ and ascitis $(\mathrm{p}=0.008)$. Using multivariate analysis, First line laparoscopy was more frequent in women with abnormal serum tumor markers $(\mathrm{OR}=9.63$; 95\% $\mathrm{CI}=1.40-66.39$; $\mathrm{p}=0.02$ ). Women with abnormal serum tumor markers were more likely to have intraoperative histology $(\mathrm{p}=0.04)$ and complete staging $(\mathrm{p}=0.0008)$ (Table 4).

Women with normal and abnormal tumor markers did not differ in terms of their mean age, familial history of cancer, parity (including nulliparity), menopausal status, presenting symptoms, or the use of preoperative CT scan, first-line laparoscopy and conservative treatment. Likewise, there was no difference in mean follow-up, disease-free survival or the recurrence rate. 
Recurrence was more frequent after conservative treatment $(\mathrm{OR}=4.44 ; 95 \% \mathrm{CI}=1.10$ 18; $\mathrm{p}=0.04)$ and in women with FIGO stage $>\mathrm{Ia}(\mathrm{OR}=7.84 ; 95 \% \mathrm{CI}=1.73-35.48 ; \mathrm{p}=0.0008)$. Abnormal serum tumor marker status was not associated with the risk of recurrence (Table 5).

\section{Serum tumor markers during follow-up}

Eighty-three women had routine serum tumor marker assays during follow-up, four times during the first year and then twice a year. Six women had abnormal results, of whom four had recurrences and two were recurrence-free, as shown by surgery. Seven women with normal serum tumor marker status during follow-up had recurrences diagnosed on clinical and/or sonographic grounds. The sensitivity, specificity and positive and negative predictive values of abnormal serum tumor maker status for recurrences were $66.6 \%, 90.1 \%, 36.4 \%$ and 97.2\%; and their accuracy was $89.2 \%$. 


\section{DISCUSSION}

In this large retrospective study, serum tumor marker assays modified the surgical management of women with borderline ovarian tumors. Moreover, serum tumor marker abnormalities during follow-up led to the diagnosis of recurrences.

\section{Low incidence of abnormal serum markers in women with borderline ovarian tumors}

Our results confirm the low frequency of serum tumor marker abnormalities in both serous and mucinous BOT, as previously shown in small series. Despite sonographic detection of large or complex ovarian tumors in our patients, and despite their management in specialized centers, less than two-thirds of the women were prescribed serum tumor marker assays. Possible explanations include the high frequency $(\sim 50 \%)$ of normal serum tumor marker status in stage I ovarian cancer (26), and the fact that several benign disorders (endometriosis, uterine fibroids, pelvic infection, etc.) can be accompanied by elevated serum tumor marker levels. Moreover, using a mathematical model, Timmerman et al underlined the low contribution of CA125 serum tumor marker to distinguish benign from malignant ovarian tumours (21). A previous study has also shown that the sensitivity and specificity of abnormal serum tumor marker status for malignant ovarian lesions are higher in menopausal women (27). In the present study, the main determinants of tumor marker assay prescription were older age, menopausal status, and ascitis on sonography.

Impact of preoperative determination of serum tumor markers on management of women with borderline ovarian tumor.

Interestingly, preoperative tumor marker assays modified patient management. Indeed, women who had these assays were more likely to have intra-operative histology and, hence, complete staging. Routine preoperative serum tumor marker assay raises issues of costeffectiveness, and can generate anxiety if the results are abnormal. Several algorithms based 
on epidemiological characteristics, serum tumor markers and sonography have been proposed for predicting the histological nature of adnexal masses (21). Despite their reported accuracy, routine use of such algorithms is limited by their complexity. In our study, multivariate analysis showed that abnormal preoperative serum tumor marker status influenced the surgical management of adnexal masses that were subsequently shown to be BOT. Although no report have focused on the prognostic relevance of abnormal serum tumor markers, our data underlined the risk of radical treatment in women with pre-operative abnormal tumor markers, even though there is no proven benefit for patients. Using preoperatively a multiple bioassay utilizing Human epididymal secretory protein E4 (He4) an CA125 in patients with a pelvic mass could be of interest in classifying patients in a high risk group of epithelial ovarian cancer (28). Serum He4 concentration may differentiate malignant ovarian tumors from endometriotic cysts (29-30). However, data concerning assessment of He4 especially in BOT are scarce and need further studies.

\section{Impact of abnormal serum tumor markers on surgical management of women with borderline ovarian tumor}

Abnormal serum tumor marker status was associated with first-line laparoscopy. There are several possible explanations for this apparent paradox. First, by permitting complete evaluation of the abdominal cavity, laparoscopy contributes to the choice of the surgical route. When macroscopic criteria suggest a benign tumor, an exclusively laparoscopic procedure is considered acceptable. In contrast, a median abdominal incision is often preferable when there are signs of malignity. Second, laparoscopy permits adequate evaluation of the feasibility of optimal surgery or the need for neoadjuvant chemotherapy (31). Finally, laparoscopic surgery has been shown to be reliable for BOT $(12-13,22,25,32)$.

\section{Relevance of serum tumor marker determination for recurrence detection.}


The contribution of serum tumor markers to the follow-up of women with BOT is controversial. This could be due to the relatively low incidence of abnormal serum tumor markers in women with BOT, both preoperatively and during recurrences $(8,13,22,25,32)$. In our study, only $83(26.2 \%)$ of 317 women with BOT had routine serum tumor marker assays during follow-up, whereas our findings show that isolated abnormal serum tumor markers can lead to the diagnosis of recurrence.

There is no consensus on the indications of serum tumor marker assays in women treated for BOT. Despite both the low incidence of abnormal serum markers in women with BOT and their low contribution to differentiate benign from malignant ovarian tumors, our results support that the preoperative evaluation of serum tumors markers modified surgical management by increasing the use of first line laparoscopy, intra operative histology and complete staging. Previous studies have shown the high risk of recurrence of serous BOT, probably owing to the higher frequency of bilateral tumors than in women with mucinous BOT. Seidman and Kurman reported that women with serous BOT exhibiting micropapillary features, and women with mucinous BOT with intraepithelial carcinoma, had a higher risk of recurrence (33). Conservative surgery based on cystectomy exposes women to a high risk of persistent and/or recurrent BOT $(7,15,32)$. As previously reported especially in case of invasive implants, women with FIGO stage > Ia BOT have a high risk of recurrence (32). Finally, nearly $80 \%$ of recurrences are diagnosed during the first two postoperative years (15, 22). It thus seems logical to recommend close follow-up of women treated for BOT, including serum tumor marker determination every 6 months for at least the first two postoperative years. This is particularly the case after conservative treatment, in patients with FIGO stage > Ia, and in patients with serous BOT with micropapillary features or mucinous BOT with intraepithelial carcinoma and in case of microinvasion on tumors or on implants. However, the use of CA125 in the follow up of patients with BOT has been recently discussed to detect 
recurrence while representing a source of patient's anxiety (34). Further studies are required to evaluate the cost-effectiveness of CA125 determination in the follow-up of women with BOT.

Regarding the limitations of this study, its retrospective nature carries a risk of bias due to confounding factors. Also, our conclusions cannot be extended to patients with other complex but histological benign ovarian tumors. Tumor markers were not assayed in all the women who had recurrences, limiting the impact of our conclusions. Indeed, pre- and postoperative serum tumor markers determinations were not available for all patients experiencing a recurrence in stage I BOT. Moreover, no evaluation of CEA serum level according to smokers or non-smokers had been performed. However, this remains the largest study of the contribution of serum tumor markers to the management of borderline ovarian tumors.

In conclusion, our results suggest that serum tumor markers can improve the preoperative assessment and surgical management of BOT, notably by increasing the use of intra-operative histology. We therefore suggest evaluating serum tumor marker assays for all women with complex adnexal tumors. Moreover, isolated serum tumor marker abnormalities during follow-up can lead to the diagnosis of recurrence. 


\section{REFERENCES}

1. International Federation of Gynecology and Obstetrics. Classification and staging of malignant tumors in the female pelvis. Acta Obstet Gynecol Scand 1971;50:1-7.

2. Scully RE. World Health Organization classification and nomenclature of ovarian cancer. Natl Cancer Inst 1975;42:5-7.

3. Bostwick DG, Tazelaar HD, Ballon SC, Hendrickson MR, Kempson RL. Ovarian epithelial tumors of borderline malignancy. A clinical and pathologic study of 109 cases. Cancer 1986;58:2052-65.

4. International Federation of Gynaecoloy and Obstetrics. Annual report and results of treatment in gynaecologic cancer. Int J Gynaecol Obstet 1989;28:189-90.

5. Rota SM, Zanetta G, Ieda N, et al. Clinical relevance of retroperitoneal involvement from epithelial ovarian tumors of borderline malignancy. Int J Gynecol Cancer 1999;9:477-80.

6. Tazelaar HD, Bostwick DG, Ballon SC, Hendrickson MR, Kempson RL. Conservative treatment of borderline ovarian tumors. Obstet Gynecol 1985;66:417-42.

7. Lim-Tan SK, Cajigas HE, Scully RE. Ovarian cystectomy for serous borderline tumors: a follow-up study of 35 cases. Obstet Gynecol 1988;72:775-81.

8. Morice P, Camatte S, El Hassan J, Pautier P, Duvillard P, Castaigne D. Clinical outcomes and fertility after conservative treatment of ovarian borderline tumors. Fertil Steril 2001;75:92-6.

9. Morice P, Camatte S, Wicart-Poque F, et al. Results of conservative management of epithelial malignant and borderline ovarian tumours. Hum Reprod Update. 2003;9:185-92.

10. Morice P. Borderline tumours of the ovary and fertility. Eur J Cancer 2006;42:149-58.

11. Donnez J, Munschke A, Berliere M, et al. Safety of conservative management and fertility outcome in women with borderline tumors of the ovary. Fertil Steril 2003;79:1216-21. 
12. Fauvet R, Boccara J, Dufournet C, David-Montefiore E, Poncelet C, Darai E. Restaging surgery for women with borderline ovarian tumors: results of a French multicenter study. Cancer 2004;100:1145-51.

13. Fauvet R, Boccara J, Dufournet C, Poncelet C, Darai E. Laparoscopic management of borderline ovarian tumors: results of a French multicenter study. Ann Oncol 2005;16:403-10. 14. Fauvet R, Poncelet C, Boccara J, Descamps P, Fondrinier E, Darai E. Fertility after conservative treatment for borderline ovarian tumors: a French multicenter study. Fertil Steril 2005;83:284-90.

15. Poncelet C, Fauvet R, Boccara J, Darai E. Recurrence after cystectomy for borderline ovarian tumors: results of a French multicenter study. Ann Surg Oncol 2006;13:565-71.

16. Hricak H. MRI of the female pelvis: a review. AJR 1986;146:1115-22.

17. Molina R, Ojeda B, Filella X, et al. A prospective study of tumor markers CA 125 and CA 19.9 in patients with epithelial ovarian carcinomas. Tumour Biol 1992;13:278-86.

18. Tamakoshi K, Kikkawa F, Shibata K, et al. Clinical value of CA125, CA19-9, CEA, CA72-4, and TPA in borderline ovarian tumor. Gynecol Oncol 1996;62:67-72.

19. Takemori M, Nishimura R, Hasegawa K. Clinical evaluation of MRI in the diagnosis of borderline ovarian tumors. Acta Obstet Gynecol Scand. 2002;81:157-61.

20. Bazot M, Nassar-Slaba J, Thomassin-Naggara I, Cortez A, Uzan S, Darai E. MR imaging compared with intraoperative frozen-section examination for the diagnosis of adnexal tumors; correlation with final histology. Eur Radiol 2006 Mar 18; Epub ahead of print.

21. Timmerman D, Van Calster B, Jurkovic D, et al. Inclusion of CA-125 does not improve mathematical models developed to distinguish between benign and malignant adnexal tumors. J Clin Oncol 2007;25:4194-200.

22. Darai E, Teboul J, Walker F, et al. Epithelial ovarian carcinoma of low malignant potential. Eur J Obstet Gyneco Reprod Biol 1996;66:141-5. 
23. Gottlieb WH, Soriano D, Achiron R, et al. CA125 measurement and ultrasonography in borderline tumors of the ovary. Am J Obstet Gynecol 2000;183:541-6.

24. Engelen MJ, De Bruijn HW, Hollema H, et al. Serum CA125, carcinoembryonic antigen, and CA19-9 as tumor markers in borderline ovarian tumors. Gynecol Oncol 2000;78:16-20.

25. Zanetta G, Rota S, Lissoni A, Meni A, Brancatelli G, Buda A. Ultrasound, physical examination, and CA125 measurement for the detection of recurrence after conservative surgery for early borderline ovarian tumors. Gynecol Oncol 2001;81:63-6.

26. Bast RC Jr, Badgwell D, Lu Z, et al. New tumor markers: CA125 and beyond. Int J Gynecol Cancer 2005;15:274-81.

27. Malkasian GD Jr, Knapp RC, Lavin PT, et al. Preoperative evaluation of serum CA 125 levels in premenopausal and postmenopausal patients with pelvic masses: discrimination of benign from malignant disease. Am J Obstet Gynecol 1988;159:341-6.

28. Moore R, McMeekin D, Brown A et al. A novel multiple marker bioassay utilizing He4 and CA 125 for the prediction of ovarian cancer in patients with a pelvic mass. Gynecol Oncol 2009;112:40-6.

29. Huhtinen K, Suvitie P, Hiissa J et al. Serum He4 concentration differentiates malignant ovarian tumours from ovarian endometriotic cyst. Br J Cancer 2009;100:1315-9.

30. Montagnana M, Lippi G, Danese E, Franchi M, Guidi G. Usefulness of serum He4 in endometriotic cysts. Br J Cancer 2009;101:548.

31. Fagotti A, Fanfani F, Ludovisi M, et al. Role of laparoscopy to assess the chance of optimal cytoreductive surgery in advanced ovarian cancer: a pilot study. Gynecol Oncol 2005;96:729-35.

32. Maneo A, Vignali M, Chiari S, Colombo A, Mangioni C, Landoni F. Are borderline tumors of the ovary safely treated by laparoscopy? Gynecol Oncol 2004;94:387-92. 
33. Seidman JD, Kurman RJ. Subclassification of serous borderline tumors of the ovary into benign and malignant types. A clinicopathologic study of 65 advanced stage cases. Am J Surg Pathol 1996;20:1331-45.

34. Oskay-Oezcelik G, du Bois A, Fasching PA, Mahner S, Liebrich C, GlaßA, SchmidtWetze S, Sepp L, Münstedt K, Lichtenegger W, Sehouli J. What do patients think about CA125 monitoring in the follow-up? Results from a multicenter trial in 1060 patients with ovarian cncer. American Society of Clinical Oncology (ASCO) Meeting 2009. Abstract number 5522, JCO, 2009; 27 (15S) : 282S. 
Table 1: Preoperative CA125, CA19-9, CEA, and CA15-3 assay in women with serous and mucinous borderline ovarian tumors.

\begin{tabular}{|l|c|c|c|c|c|}
\hline & CA125 & CA19-9 & CEA & CA15-3 & All tumor \\
\hline Serous BOT & N & N & N & N & markers \\
\hline Patients with tumor & $113 / 181$ & $45 / 180$ & $59 / 180$ & $13 / 181$ & $13 / 181$ \\
marker assays & & & & & \\
\hline Patients with at least one & $51 / 113$ & $8 / 45$ & $2 / 59$ & $2 / 13$ & \\
abnormal marker & & & & & \\
\hline Mucinous BOT & & & & & \\
\hline Patients with tumor & $89 / 136$ & $46 / 132$ & $52 / 133$ & $10 / 133$ & $10 / 136$ \\
\hline marker assays & & & & & \\
\hline Patients with at least one & $31 / 89$ & $11 / 46$ & $4 / 52$ & $2 / 10$ & \\
abnormal marker & & & & & \\
\hline
\end{tabular}


Table 2: Epidemiologic characteristics of women with serous or mucinous borderline ovarian tumours according to tumour marker status.

\begin{tabular}{|c|c|c|c|}
\hline Criteria & $\begin{array}{l}\text { Patients with } \\
\text { marker assays } \\
(\mathrm{n}=205)\end{array}$ & $\begin{array}{l}\text { Patients without } \\
\text { marker assays } \\
(\mathrm{n}=112)\end{array}$ & $\mathbf{P}$ \\
\hline Age $($ mean \pm SD) & $49.0 \pm 1.1$ & $42.8 \pm 1.5$ & 0.001 \\
\hline Parity (mean \pm SD) & $1.5 \pm 0.1$ & $1.2 \pm 0.1$ & 0.03 \\
\hline Nulliparous & $64 / 205$ & $52 / 112$ & 0.01 \\
\hline Post-menopausal & $84 / 202$ & $30 / 110$ & 0.017 \\
\hline Ascitis on sonography & $25 / 86$ & $5 / 45$ & 0.09 \\
\hline Preoperative abdominopelvic CT & $67 / 161$ & $17 / 86$ & $<0.0001$ \\
\hline Preoperative abdominopelvic MRI & $22 / 157$ & $5 / 96$ & 0.03 \\
\hline Peritoneal washing & $155 / 204$ & $48 / 111$ & $<0.0001$ \\
\hline Omentectomy & $88 / 205$ & $35 / 111$ & 0.06 \\
\hline Random peritoneal biopsies & $92 / 205$ & $20 / 110$ & $<0.0001$ \\
\hline Intra-operative histology & $108 / 159$ & $24 / 67$ & $<0.0001$ \\
\hline Conservative treatment & $77 / 205$ & $68 / 112$ & 0.0001 \\
\hline Complete staging during first surgery & $49 / 178$ & $10 / 90$ & 0.004 \\
\hline Recurrence & $13 / 205$ & $16 / 112$ & 0.03 \\
\hline
\end{tabular}

Patients with missing data were excluded from the analysis. 
Table 3: Impact of abnormal serum tumor markers on surgical management of women with serous or mucinous borderline ovarian tumors who had tumoral marker assays.

\begin{tabular}{|l|c|c|c|}
\hline Characteristic & Abnormal & Normal marker & P \\
& marker status & status & \\
& $(\mathbf{9 3}$ patients $)$ & $\mathbf{( 1 1 2}$ patients $)$ & \\
\hline Exclusive laparoscopic surgery & $16 / 29$ & $40 / 50$ & 0.007 \\
\hline Converted laparoscopy & $13 / 29$ & $10 / 50$ & 0.007 \\
\hline First-line laparotomic surgery & $64 / 93$ & $62 / 112$ & 0.007 \\
\hline Intra-operative histology & $53 / 68$ & $49 / 80$ & 0.04 \\
\hline Complete staging during first surgery & $33 / 79$ & $15 / 88$ & 0.0008 \\
\hline
\end{tabular}

Patients with missing data were excluded from the analysis. 
Table 4: Logistic regression analysis with first-line laparoscopy as the response variable and including serum marker levels as the explanatory variable (number of observations =69).

\begin{tabular}{|c|c|c|c|c|c|c|}
\hline \multirow[t]{2}{*}{ Parameters selected } & \multicolumn{3}{|c|}{ Univariate analysis } & \multicolumn{3}{|c|}{ Multivariate analysis } \\
\hline & OR & $95 \% \mathrm{CI}$ & $p$-value & Adjusted OR & $95 \% \mathrm{CI}$ & $p$-value \\
\hline \multicolumn{7}{|l|}{ Clinical } \\
\hline Age (years) & 0.97 & $0.96-0.99$ & 0.0001 & & & \\
\hline HRT & 1.53 & $0.66-3.54$ & 0.32 & & & \\
\hline Nulliparity & 1.75 & $1.11-2.79$ & 0.02 & & & \\
\hline Infertility & 3.27 & $1.55-6.91$ & 0.007 & & & \\
\hline Family history & 0.98 & $0.51-1.90$ & 0.95 & & & \\
\hline \multicolumn{7}{|l|}{ Imaging } \\
\hline US visible ascitis & 0.22 & $0.09-0.59$ & 0.001 & 0.03 & $0.00-0.55$ & 0.02 \\
\hline US tumor size $(\mathrm{mm})$ & 0.84 & $0.79-0.89$ & $<10^{-4}$ & 0.78 & $0.66-0.92$ & 0.003 \\
\hline US bilateral tumor & 0.91 & $0.50-1.65$ & 0.76 & 0.05 & $0.01-0.55$ & 0.01 \\
\hline \multicolumn{7}{|l|}{ Biological } \\
\hline Abnormal serum & 0.56 & $0.31-1.02$ & 0.06 & 9.63 & $1.40-66.39$ & 0.02 \\
\hline markers & & & & & & \\
\hline
\end{tabular}

$\mathrm{OR}=$ odds ratio; $95 \% \mathrm{CI}=95 \%$ confidence interval; Blank cells indicate that the variable was not included in the final model.

The model $\chi^{2}$ was 46.5 , df: $6, p=10^{-4}$. 
Table 5. Logistic regression analysis with post-operative recurrence as the response variable (number of observations $=170$ ).

\begin{tabular}{|c|c|c|c|c|c|c|}
\hline \multirow[t]{2}{*}{ Parameters selected } & \multicolumn{3}{|c|}{ Univariate analysis } & \multicolumn{3}{|c|}{ Multivariate analysis } \\
\hline & OR & $95 \% \mathrm{CI}$ & $p$-value & Adjusted OR & $95 \% \mathrm{CI}$ & $p$-value \\
\hline \multicolumn{7}{|l|}{ Clinical } \\
\hline Age (years) & 0.94 & $0.91-0.96$ & 0.0001 & & & \\
\hline Nulliparity & 4.02 & $1.81-8.92$ & 0.003 & & & \\
\hline Infertility & 3.68 & $1.47-9.17$ & 0.0003 & & & \\
\hline Family history & 1.38 & $0.50-3.86$ & 0.53 & & & \\
\hline \multicolumn{7}{|l|}{ Imaging } \\
\hline US visible ascitis & 2.09 & $0.60-7.29$ & 0.24 & & & \\
\hline US tumor size $(\mathrm{cm})$ & 0.98 & $0.91-1.05$ & 0.60 & & & \\
\hline US bilateral tumor & 2.20 & $0.95-5.10$ & 0.06 & & & \\
\hline \multicolumn{7}{|l|}{ Biological } \\
\hline Serum markers level & 3.30 & $0.85-12.85$ & 0.07 & 1.97 & $0.44-8.83$ & 0.79 \\
\hline \multicolumn{7}{|l|}{ Surgical } \\
\hline Conservative treatment & 4.39 & $1.83-10.55$ & 0.0004 & 4.44 & $1.10-18.00$ & 0.04 \\
\hline FIGO stage Ia vs others & 3.19 & $1.46-6.97$ & 0.0002 & 7.84 & $1.73-35.48$ & 0.0008 \\
\hline
\end{tabular}

$\mathrm{OR}=$ odds ratio; $95 \% \mathrm{CI}=95 \%$ confidence interval; $*$ This variable was forced into the model; Blank cells indicate that the variable was not included in the final model. The model $\chi^{2}$ was $14.0, \mathrm{df}: 3, p=0.003$. 